\title{
Influence of relative age on diagnosis and treatment of attention-deficit/hyperactivity disorder in children
}

\author{
Richard L. Morrow MA, E. Jane Garland MD, James M. Wright MD PhD, Malcolm Maclure ScD, \\ Suzanne Taylor PharmD, Colin R. Dormuth SCD
}

\begin{abstract}
Background: The annual cut-off date of birth for entry to school in British Columbia, Canada, is Dec. 31. Thus, children born in December are typically the youngest in their grade. We sought to determine the influence of relative age within a grade on the diagnosis and pharmacologic treatment of attentiondeficit/hyperactivity disorder (ADHD) in children.
\end{abstract}

Methods: We conducted a cohort study involving 937943 children in British Columbia who were $6-12$ years of age at any time between Dec. 1, 1997, and Nov. 30, 2008. We calculated the absolute and relative risk of receiving a diagnosis of ADHD and of receiving a prescription for a medication used to treat ADHD (i.e., methylphenidate, dextroamphetamine, mixed amphetamine salts or atomoxetine) for children born in December compared with children born in January.
Results: Boys who were born in December were $30 \%$ more likely (relative risk [RR] 1.30, 95\% confidence interval $[\mathrm{Cl}] 1.23-1.37$ ) to receive a diagnosis of ADHD than boys born in January. Girls born in December were $70 \%$ more likely (RR 1.70, 95\% Cl 1.53-1.88) to receive a diagnosis of ADHD than girls born in January. Similarly, boys were $41 \%$ more likely (RR $1.41,95 \% \mathrm{Cl}$ $1.33-1.50)$ and girls $77 \%$ more likely (RR 1.77 , $95 \% \mathrm{Cl} 1.57-2.00$ ) to be given a prescription for a medication to treat ADHD if they were born in December than if they were born in January.

Interpretation: The results of our analyses show a relative-age effect in the diagnosis and treatment of ADHD in children aged 6-12 years in British Columbia. These findings raise concerns about the potential harms of overdiagnosis and overprescribing. These harms include adverse effects on sleep, appetite and growth, in addition to increased risk of cardiovascular events.
$\mathrm{A}$ ttention-deficit/hyperactivity disorder (ADHD) is the most commonly diagnosed neurobehavioural disorder in children and is widely treated with stimulant and nonstimulant medications. ${ }^{1,2}$ Although the specific causes of the disorder are unknown, both genetic and environmental factors are thought to contribute and may interact. ${ }^{3.4}$ Several studies have investigated the potential association between season of birth and incidence of ADHD. ${ }^{5-9}$ Season of birth has been studied for a number of mental and behavioural disorders, including schizophrenia, for which an association is well-established, ${ }^{10}$ and autism, for which the evidence of an association is weaker. ${ }^{11-13}$ Among studies hypothesizing a causal relation between season of birth and ADHD, a consistent seasonal pattern has not been found. ${ }^{5-9}$

Two recent studies using survey and private health plan data in the United States reported that date of birth was a predictor of diagnosis and treatment of ADHD based on the age at which the patient started school..$^{14,15}$ Because of the cut-off dates of birth for entry to kindergarten, children within the same grade may be almost one year apart in age; that is, children with birthdates just before the cut-off will be younger and may be less mature than their classmates born at other times of year. These studies found that children who were relatively younger than their peers within the same grade were more likely to receive a diagnosis or a prescription for the pharmacologic treatment of ADHD. This pattern persisted across states with school entry dates at different times of year and depended on the cut-off date rather than the season in which the child was born. This phenomenon has been termed the relative-age effect and has been found to affect outcomes in education and athletics. ${ }^{16,17}$

There have been few studies of the potential effect of children's relative age within a grade on the treatment and diagnosis of ADHD, and it has not been analyzed in populations outside of the US. The reported prevalence of ADHD in the US is high relative to international comparisons, and
Competing interests:

Richard Morrow, E. Jane Garland, James Wright,

Malcolm Maclure and Colin Dormuth received a

Catalyst grant from the Canadian Institutes of Health Research to study postmarket drug safety and effectivness. Malcolm

Maclure is employed by the University of British

Columbia and the British Columbia Ministry of Health. Suzanne Taylor is employed by the British Columbia Ministry of Health.

This article has been peer reviewed.

Correspondence to: Richard Morrow, richard.morrow@ti.ubc.ca.

CMAJ 2012. DOI:10.1503 /cmaj.111619 
American use of medications to treat ADHD exceeds that of other developed countries, such as Canada. ${ }^{18,19}$

We were interested in knowing whether the effect of relative age was inherent in the American context (owing to underlying factors such as differences in the health care system, cultural attitudes or marketing by the pharmaceutical industry), or whether it would be present in the different context of Canada. We conducted a cohort study to explore the influence of relative age on the diagnosis and treatment of ADHD in a large sample of children with data from a nearly universal public health plan in British Columbia, Canada. The cut-off date of birth that allows entry into kindergarten or grade 1 in this province is December 31. Consequently, children born in December are typically the youngest in their grade. We hypothesized that the younger children within each grade would be more likely to have a diagnosis of ADHD and to have received prescriptions for the medications used to treat ADHD.

\section{Methods}

\section{Data sources}

We used linked data from provincial administrative health databases for prescription drugs (PharmaNet), physician services (Medical Services Plan) and hospital admissions (Canadian Institute for Health Information Discharge Abstracts Database). PharmaNet contains records of all medications dispensed at community pharmacies in British Columbia. ${ }^{20}$ Rates of underreporting and misclassification were expected to be minimal, because the quality of the data is checked when claims are transmitted. ${ }^{20}$ Similarly, data on physician services and admissions to hospital were expected to be reliable on the basis of studies comparing patient charts with administrative data in Canada. ${ }^{21,22}$ Our data were representative of most of the province's population and excluded only about $4 \%$ of residents; that is, those who are federally insured and not covered by the province's health plan, the British Columbia Medical Services Plan (i.e.,

Table 1: Percentages of boys and girls aged 6-12 years who received a diagnosis of attentiondeficit/hyperactivity disorder or treatment for the condition from a cohort of 937943 children, by birth month

\begin{tabular}{|c|c|c|c|c|c|c|}
\hline \multirow[b]{2}{*}{$\begin{array}{l}\text { Month of } \\
\text { birth }\end{array}$} & \multicolumn{3}{|c|}{ Boys } & \multicolumn{3}{|c|}{ Girls } \\
\hline & $\begin{array}{c}\text { Children, } \\
\text { no. }\end{array}$ & $\begin{array}{c}\text { Received } \\
\text { diagnosis, } \\
\%\end{array}$ & $\begin{array}{c}\text { Received } \\
\text { treatment, } \\
\%\end{array}$ & $\begin{array}{c}\text { Children, } \\
\text { no. }\end{array}$ & $\begin{array}{c}\text { Received } \\
\text { diagnosis, } \\
\%\end{array}$ & $\begin{array}{c}\text { Received } \\
\text { treatment, } \\
\%\end{array}$ \\
\hline January & 39136 & 5.7 & 4.4 & 37448 & 1.6 & 1.1 \\
\hline February & 36586 & 5.9 & 4.6 & 34791 & 1.8 & 1.3 \\
\hline March & 41512 & 6.0 & 4.7 & 38658 & 1.9 & 1.4 \\
\hline April & 40605 & 6.1 & 5.0 & 38529 & 1.9 & 1.4 \\
\hline May & 42724 & 6.5 & 5.2 & 40621 & 1.9 & 1.4 \\
\hline June & 40720 & 6.7 & 5.3 & 38808 & 2.2 & 1.7 \\
\hline July & 41829 & 7.3 & 5.8 & 40149 & 2.3 & 1.7 \\
\hline August & 40859 & 7.3 & 5.9 & 38670 & 2.4 & 1.8 \\
\hline September & 41111 & 7.6 & 6.2 & 38739 & 2.6 & 1.9 \\
\hline October & 39773 & 7.9 & 6.2 & 37967 & 2.6 & 1.9 \\
\hline November & 37409 & 7.8 & 6.2 & 35535 & 2.6 & 1.9 \\
\hline December & 38977 & 7.4 & 6.2 & 36787 & 2.7 & 1.9 \\
\hline Overall & 481241 & 6.9 & 5.5 & 456702 & 2.2 & 1.6 \\
\hline $\begin{array}{l}\text { Trend test } \\
(p \text { value })^{*}\end{array}$ & & $\begin{array}{c}-19.7 \\
(<0.0001)\end{array}$ & $\begin{array}{c}-19.3 \\
(<0.0001)\end{array}$ & & $\begin{array}{c}-16.5 \\
(<0.0001)\end{array}$ & $\begin{array}{c}-14.1 \\
(<0.0001)\end{array}$ \\
\hline $\begin{array}{l}\text { RD }(95 \% \mathrm{Cl}) \\
\text { Dec. v. Jan. }{ }^{\dagger}\end{array}$ & & $\begin{array}{c}1.71 \\
\text { (1.36 to } 2.05)\end{array}$ & $\begin{array}{c}1.80 \\
(1.48 \text { to } 2.11)\end{array}$ & & $\begin{array}{c}1.09 \\
(0.88 \text { to } 1.30)\end{array}$ & $\begin{array}{c}0.84 \\
\text { (0.66 to } 1.01)\end{array}$ \\
\hline $\begin{array}{l}\text { RR }(95 \% \mathrm{Cl}) \\
\text { Dec. v. Jan. }{ }^{\dagger}\end{array}$ & & $\begin{array}{c}1.30 \\
\text { (1.23 to } 1.37)\end{array}$ & $\begin{array}{c}1.41 \\
\text { (1.33 to } 1.50)\end{array}$ & & $\begin{array}{c}1.70 \\
(1.53 \text { to } 1.88)\end{array}$ & $\begin{array}{c}1.77 \\
\text { (1.57 to } 2.00)\end{array}$ \\
\hline $\begin{array}{l}\text { Note: } \mathrm{Cl}=\text { conf } \\
\text { *Cochran-Arm } \\
\text { tRisk of receivi } \\
\text { compared with }\end{array}$ & $\begin{array}{l}\text { nterval, RD } \\
\text { end test wit } \\
\text { gnosis of o } \\
n \text { born in Ja }\end{array}$ & $\begin{array}{l}\text { k difference, } \mathrm{RR} \\
\text { e-sided } p \text { value. } \\
\text { atment for attent } \\
\text { cy. }\end{array}$ & $\begin{array}{l}=\text { relative risk. } \\
\text { tion-deficit/hype }\end{array}$ & ty disorder & ildren born in $D$ & cember \\
\hline
\end{tabular}


Aboriginal people, prisoners, military personnel and members of the Royal Canadian Mounted Police).

\section{Study design}

The study period was Dec. 1, 1997, to Nov. 30, 2008. The study cohort comprised children between the ages of 6 and 12 years any time during the study period and who had been registered in the provincial health plan for at least one year before their entry into the cohort. Children entered the cohort when the latest of the following events occurred: their sixth birthday, the start of the study period or having been covered by the provincial health plan for one year. Followup continued until the earliest of the following events occurred: the day before their thirteenth birthday, the end of the study period or the end of coverage under the provincial health plan.

For our analysis of prescribed medications, we included methylphenidate, dextroamphetamine, mixed amphetamine salts and atomoxetine.

We placed children in categories based on their month of birth, then calculated the proportion of children who received a prescription for a medication used to treat ADHD and the proportion of patients with a diagnosis of ADHD for each month. To estimate the influence of relative age, we used these proportions to calculate the absolute risk difference (RD) and relative risk (RR) of receiving an ADHD diagnosis and of receiving a prescription for a medication to treat ADHD for children who were born in December compared with those born in January. We used a Cochran-Armitage trend test to determine the influence of relative age on diagnosis and prescribing across all months of birth.

In addition to our main analysis, we conducted analyses stratified by year and by age, and a series of sensitivity analyses. In the analysis stratified by year, we analyzed data in oneyear categories spanning December to November (e.g., 1997-98 refers to Dec. 1, 1997, to Nov. $30,1998)$. In the analysis stratified by age, we used one-year age groups from 6 to 12 years. As sensitivity analyses, we conducted the same risk calculations as in our main analysis, but changed the birthdates used to define our cohorts. We analyzed cohorts of children born Dec. 17-31 in relation to children born Jan. 1-15 (in which a relative-age effect was predicted) and compared the result with control analyses comparing the birthdate cohorts of Dec. 2-16 with Dec. 17-31, and Jan. 1-15 with Jan. 16-30 (in which no effect was expected). In addition, we analyzed the cohort of children born Dec. 28-31 relative to the cohort born Jan. 1-3.

\section{Results}

A total of 937943 children were included in our study. The percentages of children who received a diagnosis of ADHD or a prescription for medication to treat ADHD are summarized by month of birth in Table 1. The numbers of children in the cohorts born in January and December were simi-

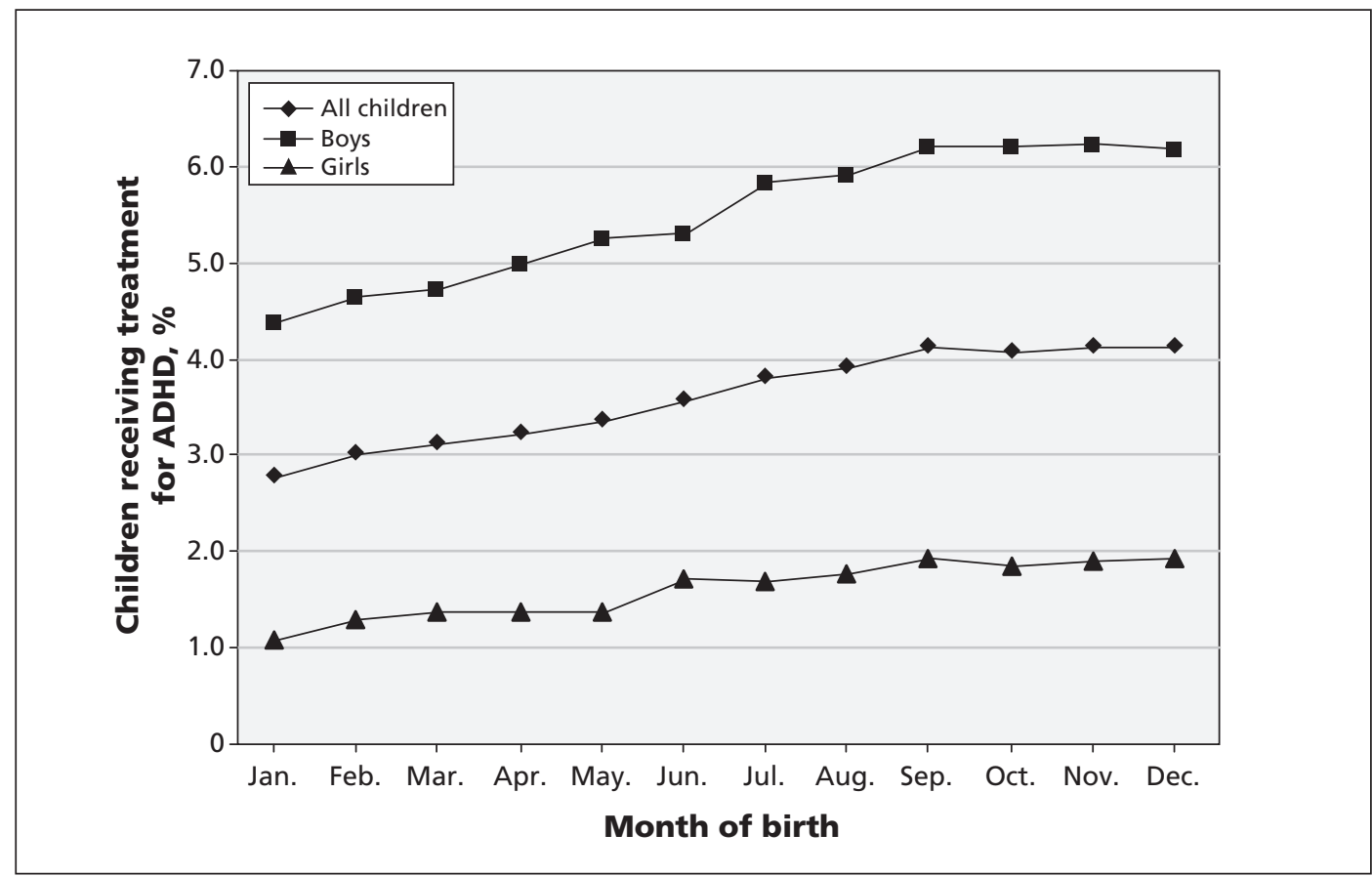

Figure 1: Percentage of children aged 6 to 12 years receiving pharmacologic treatment for ADHD, by month of birth. $A D H D=$ attention-deficit/hyperactivity disorder. 
lar. Children in both groups had a mean age of 7.8 years upon entry to the cohort (data not shown). The proportion of children receiving a diagnosis of ADHD or treatment for ADHD increased with each birth month from January to September, for both boys and girls, then plateaued until December (the percentage of boys receiving a diagnosis decreased slightly in December). These rising trends in diagnosis and treatment by birth month were confirmed with Cochran-Armitage tests (all one-sided $p$ values $<0.001$ ). The variation in ADHD treatment by birth month is presented in Figure 1, which shows an increase in the percentage of children receiving treatment by birth month.

The risk of diagnosis and treatment for ADHD among children born in December versus those born in January is reported in terms of absolute $\mathrm{RD}$ and RR in Table 1. Boys who were born in December were $30 \%$ more likely to have a diagnosis of ADHD than boys born in January, and girls born in December were $70 \%$ more likely to have a diagnosis of ADHD than girls born in January. Similarly, boys born in December were $41 \%$ more likely, and girls $77 \%$ more likely, to have a prescription for a medication to treat ADHD than their peers born in January.

The prevalence of diagnosis and treatment for ADHD increased gradually from 1997-98 to 2007-08 for both boys and girls, peaking in the most recent years (Table 2). The relative risk of diagnosis and treatment for ADHD among children born in December as compared with those born in January remained relatively stable over

Table 2: Risk of receiving a diagnosis of attention-deficit/hyperactivity disorder or treatment for the condition for children born in December compared with children born in January, by year

\begin{tabular}{|c|c|c|c|c|c|c|}
\hline \multirow[b]{3}{*}{ Year of birth* } & \multicolumn{3}{|c|}{ Diagnosis } & \multicolumn{3}{|c|}{ Treatment } \\
\hline & \multirow{2}{*}{$\begin{array}{c}\text { Children, } \\
\% \dagger\end{array}$} & \multicolumn{2}{|c|}{ Risk, December v. January } & \multirow{2}{*}{$\begin{array}{c}\text { Children, } \\
\% \dagger\end{array}$} & \multicolumn{2}{|c|}{ Risk, December v. January } \\
\hline & & RD $(95 \% \mathrm{Cl})$ & $\operatorname{RR}(95 \% \mathrm{Cl}) \ddagger$ & & RD $(95 \% \mathrm{Cl})$ & $\operatorname{RR}(95 \% \mathrm{Cl}) \ddagger$ \\
\hline \multicolumn{7}{|l|}{ Boys } \\
\hline 1997-98 & 2.6 & 0.62 (0.30 to 0.95$)$ & 1.30 (1.13 to 1.48$)$ & 3.4 & $1.04(0.67$ to 1.41$)$ & 1.39 (1.23 to 1.56$)$ \\
\hline 1998-99 & 2.6 & 0.91 (0.58 to 1.23$)$ & 1.46 (1.28 to 1.68$)$ & 3.2 & $0.97(0.61$ to 1.32$)$ & 1.40 (1.24 to 1.59$)$ \\
\hline 1999-00 & 2.6 & $0.72(0.40$ to 1.04$)$ & 1.36 (1.19 to 1.57$)$ & 3.1 & 1.07 (0.72 to 1.42$)$ & $1.47(1.29$ to 1.66$)$ \\
\hline 2000-01 & 2.5 & $0.45(0.13$ to 0.78$)$ & 1.21 (1.06 to 1.39$)$ & 3.1 & $0.88(0.53$ to 1.23$)$ & 1.37 (1.21 to 1.55$)$ \\
\hline $2001-02$ & 2.7 & $0.78(0.44$ to 1.11$)$ & 1.36 (1.19 to 1.56$)$ & 3.2 & $1.28(0.92$ to 1.64$)$ & 1.56 (1.38 to 1.77$)$ \\
\hline $2002-03$ & 3.0 & $0.77(0.42$ to 1.13$)$ & 1.32 (1.16 to 1.49$)$ & 3.3 & 1.25 (0.87 to 1.62$)$ & $1.50(1.33$ to 1.70$)$ \\
\hline $2003-04$ & 3.2 & $0.75(0.37$ to 1.12$)$ & 1.27 (1.13 to 1.43$)$ & 3.5 & $1.02(0.63$ to 1.41$)$ & $1.36(1.21$ to 1.53$)$ \\
\hline 2004-05 & 3.4 & 1.01 (0.62 to 1.40$)$ & 1.36 (1.21 to 1.54$)$ & 3.6 & 1.22 (0.82 to 1.62$)$ & $1.42(1.27$ to 1.60$)$ \\
\hline 2005-06 & 3.5 & 1.04 (0.64 to 1.44$)$ & 1.35 (1.20 to 1.52$)$ & 3.6 & 1.05 (0.64 to 1.45$)$ & 1.35 (1.20 to 1.51$)$ \\
\hline 2006-07 & 3.7 & $0.94(0.54$ to 1.35$)$ & 1.31 (1.17 to 1.47$)$ & 3.7 & 1.01 (0.59 to 1.42 ) & 1.32 (1.17 to 1.47$)$ \\
\hline $2007-08$ & 3.7 & $0.62(0.20$ to 1.03$)$ & 1.19 (1.06 to 1.34$)$ & 3.7 & $1.02(0.61$ to 1.44$)$ & 1.33 (1.18 to 1.49$)$ \\
\hline \multicolumn{7}{|l|}{ Girls } \\
\hline 1997-98 & 0.7 & 0.31 (0.13 to 0.48$)$ & 1.58 (1.21 to 2.06$)$ & 0.8 & 0.36 (0.18 to 0.55$)$ & 1.65 (1.27 to 2.13$)$ \\
\hline 1998-99 & 0.7 & 0.36 (0.19 to 0.53$)$ & 1.78 (1.35 to 2.36$)$ & 0.8 & 0.33 (0.16 to 0.50$)$ & 1.72 ( 1.30 to 2.28 ) \\
\hline 1999-00 & 0.7 & $0.29(0.12$ to 0.47$)$ & 1.57 (1.19 to 2.06$)$ & 0.8 & 0.38 (0.19 to 0.56$)$ & 1.70 (1.31 to 2.21$)$ \\
\hline $2000-01$ & 0.7 & 0.32 (0.14 to 0.50$)$ & 1.61 (1.23 to 2.10$)$ & 0.8 & 0.37 (0.19 to 0.56$)$ & 1.69 (1.30 to 2.19$)$ \\
\hline 2001-02 & 0.8 & $0.36(0.18$ to 0.55$)$ & 1.69 (1.30 to 2.21$)$ & 0.8 & 0.49 (0.30 to 0.68$)$ & 1.94 (1.49 to 2.52$)$ \\
\hline $2002-03$ & 0.9 & 0.35 (0.15 to 0.55$)$ & 1.55 (1.21 to 1.99$)$ & 0.9 & 0.50 (0.29 to 0.70$)$ & 1.79 (1.41 to 2.29$)$ \\
\hline 2003-04 & 1.0 & 0.51 (0.30 to 0.72$)$ & 1.80 (1.41 to 2.29$)$ & 1.0 & $0.43(0.21$ to 0.64$)$ & 1.57 (1.25 to 1.98$)$ \\
\hline $2004-05$ & 1.1 & 0.57 (0.35 to 0.78$)$ & 1.83 (1.44 to 2.31$)$ & 1.1 & 0.63 (0.41 to 0.85$)$ & 1.93 (1.53 to 2.44$)$ \\
\hline 2005-06 & 1.1 & $0.48(0.26$ to 0.70$)$ & 1.64 (1.30 to 2.06$)$ & 1.1 & 0.61 (0.39 to 0.84$)$ & 1.86 (1.48 to 2.36$)$ \\
\hline 2006-07 & 1.1 & 0.69 (0.45 to 0.92$)$ & 1.97 (1.56 to 2.48 ) & 1.1 & 0.67 (0.44 to 0.90$)$ & 1.96 ( 1.55 to 2.48 ) \\
\hline $2007-08$ & 1.2 & 0.63 (0.38 to 0.87$)$ & 1.74 (1.40 to 2.18$)$ & 1.1 & 0.75 (0.51 to 0.98$)$ & 2.06 (1.63 to 2.60$)$ \\
\hline $\begin{array}{l}\text { Note: } \mathrm{Cl}=\text { confi } \\
\text { *Data are grou } \\
\text { tChildren born } \\
\neq \chi^{2} \text { tests for het } \\
(p>0.9) \text { for dia }\end{array}$ & $=5$. & $\begin{array}{l}\text { erence, } R R=\text { relativ } \\
\text { mber of the followi } \\
\text { to received a diagno } \\
\text { cross yearly strata. A } \\
\text { for treatment. }\end{array}$ & $\begin{array}{l}\text { (e.g., 1997-98 ref } \\
\text { r treatment for at } \\
\text { oys, } \chi^{2}=8.3(p=\end{array}$ &  & $\begin{array}{l}\text { v. } 30,1998) \text {. } \\
\text { ity disorder. } \\
7.6(p=0.7) \text { for tre }\end{array}$ & among girls, $\chi^{2}=3.7$ \\
\hline
\end{tabular}


time, with no statistically significant heterogeneity in risk across yearly strata (Table 2). An elevated risk of diagnosis and treatment for ADHD among children born in December compared with January was present for all ages from 6 to 12 years (Table 3). The RR for girls born in December diminished at the higher end of this age range for both diagnosis and treatment $\left(\chi^{2}\right.$ tests for heterogeneity of RR $p<0.05$ for diagnosis and $p<$ 0.001 for treatment).

\section{Sensitivity analyses}

In our sensitivity analyses, children born during the last two weeks of the year were at higher risk of receiving a diagnosis of ADHD or treatment for the condition than were children born in the first two weeks of the year (analysis 1 in Table 4), in results similar to those of our main analyses. Our control analyses of periods within December and January produced results close to the null (analyses 2 and 3 in Table 4). When we considered cohorts of children born within three days before and after the cut-off for entry to school, the results were similar to those of our main analyses (analysis 4 in Table 4). Risk of diagnosis and treatment among boys was compa- rable with the results of our analysis by birth month; for girls, the risks were in the expected direction, but our sample was small and the risk of treatment was not statistically significant.

\section{Interpretation}

\section{Main findings}

Our results show a pattern of treating and diagnosing ADHD among children aged 6-12 years in British Columbia that is consistent with a relative-age effect. Children born during the month preceding the province's cut-off date for entry to school are typically the youngest and least mature within their grade, and are at a higher risk for treatment and diagnosis of ADHD. Our sensitivity analyses support this interpretation and discourage the alternative interpretation that an underlying seasonality related to the cause of the disorder is producing this effect. A sudden change in risk appears to coincide with the cut-off date for entry to school at the end of the calendar year. Even children born during the three days before the end of the calendar year had a higher risk than children born during the first three days of the following year,

Table 3: Risk of receiving a diagnosis of attention-deficit/hyperactivity disorder or treatment for the condition for children born in December compared with children born in January, by age

\begin{tabular}{|c|c|c|c|c|c|c|}
\hline \multirow[b]{3}{*}{ Age, yr } & \multicolumn{3}{|c|}{ Diagnosis } & \multicolumn{3}{|c|}{ Treatment } \\
\hline & \multirow[b]{2}{*}{$\begin{array}{c}\text { Children, } \\
\% *\end{array}$} & \multicolumn{2}{|c|}{ Risk, December v. Jananuary } & \multirow[b]{2}{*}{$\begin{array}{c}\text { Children, } \\
(\%)^{*}\end{array}$} & \multicolumn{2}{|c|}{ Risk, December v. January } \\
\hline & & RD $(95 \% \mathrm{Cl})$ & $\operatorname{RR}(95 \% \mathrm{Cl}) \dagger$ & & $\mathrm{RD}(95 \% \mathrm{Cl})$ & $\operatorname{RR}(95 \% \mathrm{Cl}) \dagger$ \\
\hline \multicolumn{7}{|l|}{ Boys } \\
\hline 6 & 2.3 & $0.82(0.56$ to 1.08$)$ & $1.48(1.31$ to 1.68$)$ & 1.6 & 0.71 (0.48 to 0.93$)$ & 1.59 (1.37 to 1.85$)$ \\
\hline 7 & 3.1 & $0.96(0.65$ to 1.26$)$ & 1.38 (1.25 to 1.53$)$ & 2.6 & $1.02(0.75$ to 1.30$)$ & 1.53 (1.36 to 1.72$)$ \\
\hline 8 & 3.4 & $1.12(0.81$ to 1.43$)$ & 1.42 (1.28 to 1.56$)$ & 3.4 & 1.30 (0.99 to 1.62$)$ & 1.50 (1.36 to 1.65$)$ \\
\hline 9 & 3.6 & 0.90 (0.58 to 1.22$)$ & 1.30 (1.18 to 1.43$)$ & 4.0 & 1.24 (0.91 to 1.57 ) & 1.41 (1.29 to 1.54$)$ \\
\hline 10 & 3.5 & 0.60 (0.29 to 0.92$)$ & 1.20 (1.09 to 1.31$)$ & 4.3 & 1.24 (0.90 to 1.58$)$ & 1.37 (1.26 to 1.49 ) \\
\hline 11 & 3.3 & 0.73 (0.43 to 1.03$)$ & $1.27(1.15$ to 1.40$)$ & 4.3 & 1.32 (0.97 to 1.66$)$ & $1.38(1.27$ to 1.50$)$ \\
\hline 12 & 3.0 & 0.63 (0.35 to 0.92$)$ & 1.25 (1.13 to 1.38$)$ & 4.2 & 1.14 (0.81 to 1.48$)$ & 1.34 (1.23 to 1.46$)$ \\
\hline \multicolumn{7}{|l|}{ Girls } \\
\hline 6 & 0.7 & 0.39 (0.24 to 0.54$)$ & 1.83 (1.44 to 2.32 ) & 0.4 & 0.21 (0.10 to 0.33$)$ & 1.74 (1.28 to 2.37 ) \\
\hline 7 & 0.9 & 0.41 (0.24 to 0.57$)$ & 1.68 (1.36 to 2.08$)$ & 0.7 & $0.45(0.30$ to 0.59$)$ & 2.04 (1.60 to 2.60$)$ \\
\hline 8 & 1.0 & 0.68 (0.50 to 0.86$)$ & 2.11 (1.73 to 2.57$)$ & 0.9 & 0.62 (0.45 to 0.79$)$ & 2.19 (1.76 to 2.71$)$ \\
\hline 9 & 1.1 & 0.67 (0.49 to 0.86$)$ & 1.90 (1.59 to 2.28$)$ & 1.2 & 0.87 (0.68 to 1.06$)$ & 2.25 (1.88 to 2.70 ) \\
\hline 10 & 1.0 & 0.43 (0.26 to 0.60$)$ & 1.60 (1.32 to 1.93$)$ & 1.2 & 0.74 (0.55 to 0.93$)$ & 2.01 (1.68 to 2.41 ) \\
\hline 11 & 0.9 & $0.38(0.21$ to 0.54$)$ & 1.54 (1.27 to 1.87$)$ & 1.2 & 0.55 (0.37 to 0.74$)$ & 1.69 (1.41 to 2.01$)$ \\
\hline 12 & 0.8 & 0.20 (0.04 to 0.36$)$ & 1.29 (1.06 to 1.57$)$ & 1.1 & 0.25 (0.08 to 0.43$)$ & 1.29 (1.08 to 1.54$)$ \\
\hline
\end{tabular}


despite being born in the same season (i.e., they were all born within a six-day period).

The attenuation in rising risk for the birth months from October to December, seen in Figure 1 and Table 1, may suggest that children predisposed to ADHD have early behaviour problems that cause them to be held back from school for a year, thus allowing them more time to develop sociable behaviour.

\section{Comparison with other studies}

The relative-age effect we report, based on population-wide public data in British Columbia, is consistent with analyses of relative age in two studies using survey and private health plan data in the US..$^{14,15}$

In our study, a sudden change in the percentage of children who received a diagnosis of ADHD or treatment for the condition occurs near Dec. 31, the cut-off date for entry to school in the province of British Columbia. In the American studies, a discontinuity occurred around the dates for entry to school at the different times of year for the different states. In interpreting their findings, the authors of those studies considered that the relative immaturity of

\begin{tabular}{|c|c|c|c|c|}
\hline & $\begin{array}{l}\text { Exposed } \\
\text { cohort }\end{array}$ & $\begin{array}{l}\text { Unexposed } \\
\text { cohort }\end{array}$ & $\mathrm{RD}(95 \% \mathrm{Cl})$ & $\operatorname{RR}(95 \% \mathrm{Cl})$ \\
\hline $\begin{array}{l}\text { Analysis 1, date of } \\
\text { birth }\end{array}$ & Dec. 17-31 & Jan. 1-15 & & \\
\hline Boys, no. & 14853 & 15068 & & \\
\hline Diagnosis, no. (\%) & $1085(7.3)$ & $856(5.7)$ & 1.62 (1.07 to 2.18$)$ & $1.29(1.18$ to 1.40$)$ \\
\hline Treatment, no. (\%) & $884(6.0)$ & $666(4.4)$ & 1.53 (1.03 to 2.03$)$ & 1.35 (1.22 to 1.49$)$ \\
\hline Girls, no. & 13960 & 14529 & & \\
\hline Diagnosis, no. (\%) & $376(2.7)$ & $231(1.6)$ & 1.10 (0.77 to 1.44$)$ & 1.69 (1.44 to 1.99$)$ \\
\hline Treatment, no. (\%) & $261(1.9)$ & $150(1.0)$ & 0.84 (0.56 to 1.12$)$ & 1.81 (1.48 to 2.21 ) \\
\hline
\end{tabular}

\begin{tabular}{lcccr|}
$\begin{array}{l}\text { Analysis 2, date of } \\
\text { birth }\end{array}$ & Dec. 2-16 & Dec. 17-31 & \\
\hline $\begin{array}{l}\text { Boys, no. } \\
18957\end{array}$ & 14853 \\
\hline Diagnosis, no. (\%) & $1420(7.5)$ & $1085(7.3)$ & $0.19(-0.38$ to 0.75$)$ & 1.03 (0.95 to 1.11) \\
\hline Treatment, no. (\%) & $1190(6.3)$ & $884(6.0)$ & $0.33(-0.19$ to 0.84$)$ & 1.05 (0.97 to 1.15) \\
\hline Girls, no. & 17924 & 13960 & & \\
\hline Diagnosis, no. (\%) & $469(2.6)$ & $376(2.7)$ & $-0.08(-0.43$ to 0.28$)$ & $0.97(0.85$ to 1.11$)$ \\
\hline Treatment, no. (\%) & $347(1.9)$ & $261(1.9)$ & $0.07(-0.24$ to 0.37$)$ & $1.04(0.88$ to 1.21$)$ \\
\hline
\end{tabular}

\begin{tabular}{|lccrr|}
\hline $\begin{array}{l}\text { Analysis 3, date of } \\
\text { birth }\end{array}$ & Jan. 1-15 & Jan. 16-30 & & \\
\hline Boys, no. & 15068 & 19154 & & \\
\hline Diagnosis, no. (\%) & $856(5.7)$ & $1103(5.8)$ & $-0.08(-0.57$ to 0.42$)$ & 0.99 (0.90 to 1.08) \\
\hline Treatment, no. (\%) & $666(4.4)$ & $837(4.4)$ & $0.05(-0.39$ to 0.49$)$ & 1.01 (0.92 to 1.12) \\
\hline Girls, no. & 14529 & 18179 & & \\
\hline Diagnosis, no. (\%) & $231(1.6)$ & $276(1.5)$ & $0.07(-0.20$ to 0.34$)$ & $1.05(0.88$ to 1.25$)$ \\
\hline Treatment, no. (\%) & $150(1.0)$ & $194(1.1)$ & $-0.03(-0.26$ to 0.19$)$ & $0.97(0.78$ to 1.20$)$ \\
\hline
\end{tabular}

\begin{tabular}{|c|c|c|c|c|}
\hline $\begin{array}{l}\text { Analysis 4, date of } \\
\text { birth }\end{array}$ & Dec. 29-31 & Jan. 1-3 & & \\
\hline Boys, no. & 3907 & 3609 & & \\
\hline Diagnosis, no. (\%) & $272(6.7)$ & $190(5.3)$ & 1.70 (0.62 to 2.78$)$ & 1.32 (1.10 to 1.58$)$ \\
\hline Treatment, no. (\%) & $252(6.5)$ & $155(4.3)$ & 2.16 (1.14 to 3.17$)$ & 1.50 (1.24 to 1.82$)$ \\
\hline Girls, no. & 3710 & 3491 & & \\
\hline Diagnosis, no. (\%) & $93(2.5)$ & $59(1.7)$ & 0.82 (0.16 to 1.48$)$ & 1.48 (1.07 to 2.05$)$ \\
\hline Treatment, no. (\%) & $74(2.0)$ & 49 (1.4) & 0.59 (0.00 to 1.19$)$ & 1.42 (0.99 to 2.03$)$ \\
\hline
\end{tabular}


younger students within a grade may lead to the inappropriate diagnosis of ADHD.

Although the alternative interpretations that underdiagnosis takes place in older children or that the social pressures on younger children amplify the symptoms of the disorder must also be considered, the evidence of a relative-age effect in our study raises the concern of overdiagnosis and overtreatment of ADHD in younger children within a grade. The potential harms of overdiagnosis and unnecessary pharmacologic treatments are important to consider. Children who are given medications to treat ADHD are exposed to adverse effects on sleep, appetite and growth, in addition to an increased risk of cardiovascular events. ${ }^{23}$ Inappropriate diagnosis of ADHD in a child born late in the year might lead parents and teachers to treat the child differently or adversely change the child's self-perceptions. Our analyses add weight to concerns about the medicalization of the normal range of childhood behaviours, particularly for boys.

Our data underscore the dimensional and developmental nature of the symptoms of $\mathrm{ADHD}^{24}$ and the impact of contextual expectations on the likelihood of the diagnosis being made. Age-corrected rating scales and developmentally appropriate evaluation are therefore essential, but such a strategy may not be enough to fully eliminate the relative-age effect. Confounding influences may still exist, such as the expectations of parents and teachers, or the child's self-perception in the classroom. For example, inadvertent reinforcement may magnify the apparently inattentive, distracting or impulsive behaviours of the youngest children in a class, such as escaping from a difficult academic task (negative reinforcement) or receiving attention from teachers and peers for disruptive behaviour (positive reinforcement). A previous study found that teachers' perceptions of child behaviour were more strongly related to a child's age within a grade than were parental perceptions, suggesting that

[T]eachers' opinions of children are the key mechanisms driving the relationship between school starting age and ADHD diagnoses. ${ }^{14}$

It is possible that closer consideration of a child's behaviour in multiple contexts, including those outside of school, may lessen the risk of unnecessary diagnosis when assessing children for ADHD.

\section{Limitations}

We aimed to determine the influence of birth month on diagnosing and prescribing medica- tions for ADHD, but our study faced certain limitations. To interpret the increased risk of diagnosis and treatment among younger children within a grade as overdiagnosis or overprescribing implies an assumption as to appropriate levels of diagnosis and treatment, such as that children born in January received appropriate levels of diagnoses and treatment. However, the true incidence of ADHD is unknown. The proportion of children born in January who received a diagnosis of ADHD might underestimate incidence of the disorder if more mature children within each grade are better able to cope with an underlying disorder. However, it is possible that the January proportion overestimates the incidence if a larger issue of overmedicalization of childhood behaviour exists.

\section{Conclusion}

Our analyses show a relative-age effect in the diagnosis and treatment of ADHD in children aged 6-12 years in the province of British Columbia. The strength of this effect remained relatively stable for the duration of our 11-year study. Although the prevalence of diagnosis and treatment for ADHD remains considerably higher among boys, it increased over time for children of both sexes in this age range.

Although the influence of relative age on diagnosis and treatment may lessen for older children, we found the effect was present at all ages from 6 to 12 years, for girls and boys alike. The potential harms of overdiagnosis and overprescribing and the lack of an objective test for ADHD strongly suggest caution be taken in assessing children for this disorder and providing treatment. Greater emphasis on a child's behaviour outside of school may be warranted when assessing children for ADHD to lessen the risk of inappropriate diagnosis. Further research into the determinants of ADHD and approaches to its assessment and treatment should consider a child's age within a grade.

\section{References}

1. Increasing prevalence of parent-reported attention-deficit/ hyperactivity disorder among children — United States, 2003 and 2007. MMWR Morb Mortal Wekly Rep 2010;59:1439-43.

2. Pastor PN, Reuben CA. Diagnosed attention deficit hyperactivity disorder and learning disability: United States, 2004-2006. Vital Health Stat 10 2008;Jul:1-14.

3. Nigg J, Nikolas M, Burt SA. Measured gene-by-environment interaction in relation to attention-deficit/hyperactivity disorder. J Am Acad Child Adolesc Psychiatry 2010;49:863-73.

4. Thapar A, Langley K, Asherson P, et al. Gene-environment interplay in attention-deficit hyperactivity disorder and the importance of a developmental perspective. Br J Psychiatry 2007; 190:1-3

5. Liederman J, Flannery KA. Fall conception increases the risk of neurodevelopmental disorder in offspring. J Clin Exp Neuropsychol 1994;16:754-68.

6. Mick E, Biederman J, Faraone SV. Is season of birth a risk factor for attention-deficit hyperactivity disorder? J Am Acad Child Adolesc Psychiatry 1996;35:1470-6. 
7. Seeger G, Schloss P, Schmidt MH, et al. Gene-environment interaction in hyperkinetic conduct disorder $(\mathrm{HD}+\mathrm{CD})$ as indicated by season of birth variations in dopamine receptor (DRD4) gene polymorphism. Neurosci Lett 2004;366:282-6.

8. Brookes KJ, Neale B, Xu X, et al. Differential dopamine receptor D4 allele association with ADHD dependent of proband season of birth. Am J Med Genet B Neuropsychiatr Genet 2008; 147B:94-9.

9. Atladóttir HO, Parner ET, Schendel D, et al. Variation in incidence of neurodevelopmental disorders with season of birth. Epidemiology 2007;18:240-5.

10. Tochigi M, Okazaki Y, Kato N, et al. What causes seasonality of birth in schizophrenia? Neurosci Res 2004;48:1-11

11. Hebert KJ, Miller LL, Joinson CJ. Association of autistic spectrum disorder with season of birth and conception in a UK cohort. Autism Res 2010;3:185-90.

12. Kolevzon A, Weiser M, Gross R, et al. Effects of season of birth on autism spectrum disorders: Fact or fiction? Am J Psychiatry 2006; $163: 1288-90$

13. Hauschild KM, Mouridsen SE, Nielsen S. Season of birth in Danish children with language disorder born in the 1958-1976 period. Neuropsychobiology 2005;51:93-9.

14. Elder TE. The importance of relative standards in ADHD diagnoses: evidence based on exact birth dates. J Health Econ 2010; 29:641-56.

15. Evans WN, Morrill MS, Parente ST. Measuring inappropriate medical diagnosis and treatment in survey data: the case of ADHD among school-age children. J Health Econ 2010;29:657-73.

16. Bedard K, Dhuey E. The persistence of early childhood maturity: international evidence of long-run age effects. $Q J$ Econ 2006; 121:1437-72.

17. Cobley S, Baker J, Wattie N, et al. Annual age-grouping and athlete development: a meta-analytical review of relative age effects in sport. Sports Med 2009;39:235-56.

18. Polanczyk G, de Lima MS, Horta BL, et al. The worldwide prevalence of ADHD: a systematic review and metaregression analysis. Am J Psychiatry 2007;164:942-8
19. Scheffler RM, Hinshaw SP, Modrek S, et al. The global market for ADHD medications. Health Aff (Millwood) 2007;26:450-7

20. Dormuth CR, Glynn RJ, Neumann P, et al. Impact of two sequential drug cost-sharing policies on the use of inhaled medications in older patients with chronic obstructive pulmonary disease or asthma. Clin Ther 2006;28:964-78, discussion 2-3.

21. Humphries KH, Rankin JM, Carere RG, et al. Co-morbidity data in outcomes research: Are clinical data derived from administrative databases a reliable alternative to chart review? J Clin Epidemiol 2000;53:343-9.

22. Steele LS, Glazier RH, Lin E, et al. Using administrative data to measure ambulatory mental health service provision in primary care. Med Care 2004;42:960-5.

23. Gould MS, Walsh BT, Munfakh JL, et al. Sudden death and use of stimulant medications in youths. Am J Psychiatry 2009;166: 992-1001.

24. Levy F, Hay DA, McStephen M, et al. Attention-deficit hyperactivity disorder: A category or a continuum? Genetic analysis of a large-scale twin study. J Am Acad Child Adolesc Psychiatry 1997; 36:737-44.

Affiliations: From the Department of Anesthesiology, Pharmacology and Therapeutics (Morrow, Maclure, Dormuth), University of British Columbia, Victoria, BC; the Department of Psychiatry, University of British Columbia and the Mood and Anxiety Disorders Clinic, BC's Children's Hospital (Garland), Vancouver BC; the Departments of Anesthesiology, Pharmacology and Therapeutics and of Medicine (Wright), University of British Columbia, Vancouver, BC; the Pharmaceutical Services Division of the BC Ministry of Health (Maclure), Victoria, BC; the Drug Use Optimization branch of Pharmaceutical Services Division of the BC Ministry of Health, and Faculty of Pharmaceutical Sciences (Taylor), University of British Columbia, Vancouver, BC.

Contributors: All of the authors participated in the conception and design of the study, and the analysis and interpretation of the results. Richard Morrow and Colin Dormuth drafted the manuscript, and all of the authors critically revised it and approved the final version submitted for publication.

Funding: This work was funded by a Catalyst Post-Market Drug Safety and Effectiveness grant from the Canadian Institutes of Health Research (grant DSA-103525), and by a fiveyear renewable grant to the University of British Columbia from the British Columbia Ministry of Health.

\section{Change of address}

We require 6 to 8 weeks' notice to ensure uninterrupted service. Please send your current mailing label, new address and the effective date of change to:

\section{CMA Member Service Centre}

1870 Alta Vista Dr.
Ottawa ON K1G 6R7

tel $888855-2555$ or

$613731-8610 \times 2307$

fax 613 236-8864

cmamsc@cma.ca

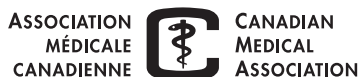

